УДК 337

DOI: $10.15673 /$ fie.v13i2.2036

\author{
Вовчак О.Д. \\ доктор економічних наук, профресор \\ кафедра банківської справи та фрінансових технологій \\ Університет банківської справи \\ вул. Січових Стрільців, 11, м. Львів, Україна, 79007 \\ E-mail: vovchak.olga@meta.ua \\ ORCID ID: 0000-0002-8858-5386 \\ Мельник О.В. \\ доктор економічних наук, доцент, \\ кафедра економічної теорії \\ Київський національний економічний університет \\ ім.Вадима Гетьмана \\ проспект Перемоги, 54/1, Київ, Україна, 03057 \\ E-mail: kina44@gmail.com \\ ORCID ID: 0000-0002-2836-8945
}

\title{
ВАРТІСНІ АСПЕКТИ УПРАВЛІНСЬКОГО ОЦІНЮВАННЯ РЕЗУЛЬТАТИВНОСТІ КАПІТАЛОТВОРЕННЯ НА ПІДПРИЕМСТВІ
}

У статті представлено результати розвитку методичного базису оцінювання управлінської результативності капіталотворення з урахуванням сучасного доробку теорії вартості підприємства. Визначено сучасну проблематику вартісного оцінювання результатів капіталотворення, ссрормовано сукупності аналітичних індикаторів оцінювання управлінської результативності капіталотворення відповідно до логіки оцінювання вартості капіталу на основі концепції економічного прибутку. У ході дослідження використано методи VBM-аналізу, ReOI-модель, метод кореляційного аналізу факторів формування вартості. Наукова новизна отриманих результатів полягає у розвитку аналітичного інструментарію вартісного оцінювання управлінської результативності капіталотворення на підприємствах. Практичне значення отриманих результатів полягає у визначенні найбільш впливових чинників з точки зору забезпечення зростання капітальних результатів вітчизняних промислових підприємств.

Ключові слова: результативність, капіталотворення, вартість, економічний прибуток, додана вартість капіталу.

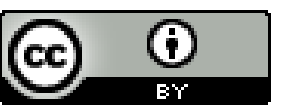

This work is licensed under a Creative Commons Attribution 4.0 International License http://creativecommons.org/licenses/by/4.0/
Постановка проблеми та її зв'язок з важливими науковими та практичними завданнями. Проблематика результативності капіталотворення підприємств є однією з найбільш актуальних як у науковому, так і бізнес-товаристві. Це пов'язано, перш за все, з тим, що у процесі капіталотворення відбувається формування доданої вартості на вкладений капітал, що, безпосередньо, забезпечує як зростання капіталізації бізнесу, так і розширює фінансові можливості щодо успішного його розвитку. Актуалізація розвитку теорії управлінської результативності капіталотворення підприємства зумовлена процесами інтелектуалізації та соціалізації суспільного виробництва, що стало каталізатором розвитку нового етапу дискусій з питань якості результатів та процесів капіталотворення. В такому контексті нового змісту набувають наукові та практичні питання, що пов'язані 3 оцінюванням управлінської результативності капіталотворення, що зумовлено зростанням пріоритетності значення нефінансових форм капіталу у забезпеченні досягнення фінансово-економічних результатів фун- кціонування та розвитку підприємства.

Аналіз останніх публікацій по проблемі. Питання оцінювання результатів формування та використання капіталу підприємств досить широко представлено у наукових публікаціях, серед яких найбільш популяризованими є праці Г. Арнольда, I. Бланка, Ю. Брігхема, А. Дамодарана, А. Раппапорт, I. Рєпіної, Л. Черникової, Л. Фролової, Г. Швиданенко, ін. Особливості оцінювання управлінської результативності капіталотврення на основі вартісного підходу досліджено у наукових працях Г. Барунова, Д. Волкова, М. Дєдкової, О. Дерев’янко, І. Івашковської, В. Когденко, М. Лотоцького, Л. Мельник, О. Мендрула, Л. Пронько, Л. Самсонової, Е. Сіванкової, Л. Сироти, О. Терещенко, Т. Теплової, А. Турила, Г. Хотинської, I. Христофорової, Н. Шевчук, ін.

Формулювання цілей дослідження. Не заперечуючи вагомості існуючого наукового доробку в аспекті оцінювання результативності капіталотворення варто зазначити, що сучасний розвиток управлінського напрямку теорії вартості підприємства ак- 
туалізує потребу в удосконаленні методів та інструментів оцінювання вартісних результатів капіталотворення відповідно до потреб менеджменту та бізнесаналітики бізнес-структур, які орієнтовані на довгострокове економічне зростання. Відповідно, метою даної статті є розвиток методичних підходів до оцінювання результатів капіталотворення на основі використання концепції економічного прибутку та актуалізації необхідності подальшого дослідження управлінської результативності з урахуванням нефінансових факторів формування вартості капіталу підприємства.

Виклад основних результатів та їх обгрунтування. Багатоаспектність сутнісних інтерпретацій капіталу підприємства та його видова неоднорідність частково пояснюють відсутність єдиної наукової позиції в питаннях оцінювання результативності управління капіталом. Традиційно, такі оцінки здійснюються у двох напрямках - витратному та результатному. 3 точки зору витратного підходу оцінювання здійснюються за критеріями мінімізації середньозважених витрат на капітал, а традиційна управлінська проблематика розглядається в руслі питань раціоналізації структури капіталу. Результатні аспекти оцінювання капіталу підприємства формалізуються у вигляді ефектів, що визначаються на основі абсолютних (величина приросту: балансової величини активів, власного капіталу, балансової вартості чистих активів, нерозподіленого прибутку, ін.) та відносних (доходність капіталу, продуктивність капіталу, ін.) вимірювань, концептуальною основою здійснення яких $є$ положення теорії бухгалтерського обліку та фінансового менеджменту [8; 9; 13].

На основі критичного аналізу наукового доробку щодо оцінювання результативності управління капіталом було встановлено, що домінуючим концептуальним напрямком є вартісний, інтерпретація якого здійснюється у різних видових категоріях вартості капіталу підприємства. 3 точки зору вартісного напрямку оцінювання результатів капіталотворення принципово можна виділити два методологічні підходи - інвестиційний та управлінський, розмежування яких дозволяє пояснити причини змістовно полярних поглядів вчених, що використовують однакову термінологію у визначенні та оцінюванні результативності управління капіталом підприємств.

В межах інвестиційного напрямку оцінювання капіталу логічного розвитку набули фондовий та фундаментально-вартісний підходи, відповідно до яких капітал підприємства розглядається як ринкова трансакція у вигляді інвестицій, що має забезпечити інвестору максимізацію ринкової доходності на вкладений капітал. Методологічною основою фундаментально-вартісного напрямку оцінювання капіталу $є$ його «природна ціна», що у сучасній термінології описується у категоріях внутрішньої, фундаментальної, інвестиційної, справедливої вартості капіталу [2$5 ; 10 ; 12]$.

Встановлено, що результатом еволюційного розвитку фундаментально-вартісного напрямку оцінювання капіталу є VBM-напрямок, основу якого формують аналітичні метрики вимірювання вартості капіталу та методи визначення вартісного зростання в межах цільових управлінських моделей бізнесу. VBMнапрямок оцінювання управлінських результатів капіталотворення $є$ сфокусованим на фундаментальних факторах формування вартості, а відповідні результати формалізуються на основі абсолютної величини вартості у грошову вимірюванні та на основі аналізу вартісного зростання.

За результатами критичного аналізу методологічних підходів до оцінювання результатів капіталотворення на основі дисконтування грошових потоків (DCFM, Discounted Cash Flows Models) та концепції економічного прибутку (EPM, Economic Profit Model) було встановлено, що якщо метою оцінювання капіталу $є$ визначення результативності управлінських впливів, то найбільш доцільно з точки зору використання $є$ методологія оцінювання вартості капіталу, що базується на концепції економічного прибутку [9; 12]. 3 точки зору характеристики аналітичного потенціалу можемо говорити про те, що EPM має більш високий рівень факторної інтерпретації, що дозволяє визначити як на найбільш слабкі аспекти капіталотворення, так і зробити прогнозні оцінки базових параметрів формування вартості капіталу, які мають бути забезпечені з точки зору здійснення управлінських впливів на капітал у майбутньому.

Варто зазначити, що здійснюючи оцінювання результативності капіталотворення на підприємствах не доцільно робити висновки лише за показниками величина вартості капіталу та їі динаміки. Оцінювання управлінської результативності доцільно здійснювати на основі сукупності аналітичних індикаторів, які формуються відповідно до тієї методологічної основи, яку закладено в основу розрахунку вартості капіталу.

Відповідно даної логіки сформовано системи показників оцінювання вартісних результатів капіталотворення відповідно до методології розрахунку вартості капіталу на основі моделі остаточного операційного прибутку (ReOI-модель), а імплементацію даної методичної пропозиції зроблено у практику діяльності промислових підприємств України, серед яких обрано харчові, металургійні та машинобудівні, як такі, що є основою забезпечення капіталізації вітчизняної промисловості.

Так, станом на початок 2019 р. частка фундаментальної вартості капіталу у ії загальнопромисловій величині становила для харчових підприємств $15,91 \%$, металургійних - 3,45\%, машинобудівних $5,73 \%$ (табл. 1). Доцільно звернути увагу на той факт, що відповідні значення показників у порівнянні 3 2010 р. є: для харчових підприємств більшими у 1,57 рази, для металургійних та машинобудівних меншими у 4,34 рази та 2,31 рази відповідно.

Основними вартість формуючим фактором для досліджуваних промислових підприємств є балансова вартість чистих активів та додана вартість, що генерує функціонуючий капітал. Щодо балансової вартості чистих активів, то для харчових підприємств в цілому є характерною зростаюча тенденція і на початку 2019 р. вона перевищувала аналогічний показник початку 2011 р. на 137,8\%. 


\begin{tabular}{|c|c|}
\hline $\begin{array}{c}\text { 1. Показники величини та структури } \\
\text { вартості капіталу }\end{array}$ & $\begin{array}{l}\text { 2. Показники структури та динаміки } \\
\text { доданої вартості капіталу }\end{array}$ \\
\hline $\begin{array}{l}\text { Вартість капіталу. } \\
\text { Балансова вартість чистих активів. } \\
\text { Додана вартість капіталу (остаточний операційний } \\
\text { прибуток). } \\
\text { Частка доданої вартості у загальній величині варто- } \\
\text { сті капіталу. } \\
\text { Частка балансової вартості чистих активів у загаль- } \\
\text { ній величині вартості капіталу. }\end{array}$ & $\begin{array}{l}\text { Спред прибутковості капіталу. } \\
\text { Спред прибутковості реалізації продукції. } \\
\text { Балансова величина капіталу. } \\
\text { Виручка від продажу продукції. } \\
\text { Інше. }\end{array}$ \\
\hline $\begin{array}{l}\text { 2. Показники структури спред результатів } \\
\text { капіталотворення }\end{array}$ & 4. Показники вартісного зростання \\
\hline $\begin{array}{l}\text { Рентабельність капіталу. } \\
\text { Середньозважені витрати на капітал. } \\
\text { Продуктивність активів } \\
\text { Рентабельність реалізації продукції. } \\
\text { Критичне значення рентабельності реалізації проду- } \\
\text { кції. }\end{array}$ & $\begin{array}{l}\text { Індекс стійкості зростання. } \\
\text { Темпи зростання вартості капіталу. } \\
\text { Співвідношення темпів зростання прибутку та вели- } \\
\text { чини капіталу. } \\
\text { Співвідношення темпів зростання виручки від про- } \\
\text { дажу продукції та величини капіталу } \\
\text { Інше. }\end{array}$ \\
\hline
\end{tabular}

\section{Рис. 1 - Системи вартісних індикаторів оцінювання управлінських результатів капіталотворення на підприсмстві* \\ * розроблено авторами на основі критичного узагальнення $[1 ; 6 ; 9 ; 11-13]$}

Таблиця 1

Показники формування фундаментальної вартості капіталу промислових підприсмств y 2011 - 2019 pp.*

\begin{tabular}{|c|c|c|c|c|c|c|c|c|c|}
\hline \multicolumn{10}{|c|}{ (початок року) } \\
\hline \multirow{2}{*}{ Показники } & \multicolumn{9}{|c|}{ Роки } \\
\hline & 2011 & 2012 & 2013 & 2014 & 2015 & 2016 & 2017 & 2018 & 2019 \\
\hline \multicolumn{10}{|c|}{ 1. Частка у формуванні фундаментальної вартості капіталу по промисловості в цілому, \% } \\
\hline харчові підприємства & 10,16 & 10,62 & 11,65 & 11,26 & 11,96 & 14,76 & 10,06 & 12,71 & 15,91 \\
\hline металургійні підприємства & 14,98 & 13,55 & 10,05 & 8,55 & 4,58 & 1,77 & 10,13 & 4,54 & 3,45 \\
\hline машинобудівні підприємства & 13,24 & 14,56 & 12,79 & 9,68 & 5,39 & 3,33 & 4,61 & 5,78 & 5,73 \\
\hline \multicolumn{10}{|c|}{ 2. Частка балансової вартості чистих активів у їх загальнопромисловій величині, \% } \\
\hline харчові підприємства & 10,51 & 11,71 & 10,75 & 10,53 & 11,61 & 12,55 & 12,83 & 14,52 & 18,10 \\
\hline металургійні підприємства & 17,47 & 16,83 & 14,17 & 11,38 & 12,24 & 13,78 & 13,05 & 10,56 & 7,90 \\
\hline машинобудівні підприємства & 12,46 & 12,75 & 10,76 & 9,15 & 8,26 & 6,39 & 5,30 & 5,74 & 6,12 \\
\hline \multicolumn{10}{|c|}{ 3. Темпи приросту (зменшення) фундаментальної вартості капіталу, \% до 2010 р. } \\
\hline харчові підприє & - & 17,67 & 53,59 & 78,91 & 9,10 & $-18,48$ & $-5,14$ & 54,58 & 137,8 \\
\hline металургійні підприємства & - & 1,81 & $-10,14$ & $-7,85$ & $-71,63$ & $-93,37$ & $-35,19$ & $-62,56$ & $-65,03$ \\
\hline машинобудівні підприємства & - & 23,80 & 29,36 & 18,01 & $-62,24$ & $-85,88$ & $-66,68$ & $-46,09$ & $-34,29$ \\
\hline \multicolumn{10}{|c|}{ 4. Темпи приросту (зменшення) балансової вартості чистих активів, \% до 2010 р. } \\
\hline харчові підприємства & - & 19,98 & 41,75 & 70,00 & 73,98 & 53,08 & 48,77 & 80,14 & 149,1 \\
\hline металургійні підприємства & - & 3,68 & 12,46 & 10,52 & 10,34 & 1,10 & $-9,04$ & $-21,19$ & $-34,63$ \\
\hline машинобудівні підприємства & - & 10,20 & 19,81 & 24,75 & 4,48 & $-34,24$ & $-48,11$ & $-39,91$ & $-28,89$ \\
\hline \multicolumn{10}{|c|}{ 5. Додана вартість капіталу, млн.грн } \\
\hline харчові підприємства & -10542 & -13406 & -11052 & -14997 & -39652 & -39641 & -33393 & -27385 & -29978 \\
\hline металургійні підприємства & -23710 & -25491 & -37605 & -35101 & -65856 & -69719 & -34230 & -38721 & -30220 \\
\hline машинобудівні підприємства & -8616 & -3670 & -6236 & -13634 & -37561 & -27768 & -12417 & -7822 & -8438 \\
\hline
\end{tabular}

*Розраховано та формалізовано автором за даними [7]

Металургійні та машинобудівні підприємства характеризуються спадною динамікою, що відповідним чином відобразилося на змінах вартості капіталу. Щодо доданої вартості функціонуючого капіталу, то протягом 2010 - 2018 рр. у жодному з досліджуваних випадків її величина не була позитивною. При цьому прибутковою була діяльність харчових підприємств у 6 випадках з 9, металургійних - 1, машинобудівних -
6 (табл. 2). Це означає, що прибутковість капіталу була недостатньою для покриття витрат на капітал, а відтак, потоки остаточного операційного прибутку були від’ємними. Руйнівна динаміка доданої вартості визначила і тенденції щодо вартості капіталу і лише для харчових підприємств за рахунок більш високих темпів зростання балансової вартості чистих активів руйнівні тенденції щодо вартості були змінені на 
протилежні.

Основними факторами формування доданої вартості функціонуючого капіталу є спред доходності капіталу та величина активів. У 2018 р. по всім дослі- джуваним промисловим підприємствам відбулося зростання балансової величини активів (табл. 2), при цьому темпи зростання на харчових підприємствах перевищували середні по промисловості.

Таблиця 2

Показники результатів капіталотворення промислових підприємств у 2010 - 2018 рр.

\begin{tabular}{|c|c|c|c|c|c|c|c|c|c|}
\hline \multicolumn{9}{|c|}{ (початок року) } & \\
\hline \multirow{2}{*}{ Показники } & & & & & & & & & \\
\hline & 2011 & 2012 & 2013 & 2014 & 2015 & 2016 & 2017 & 2018 & 2019 \\
\hline \multicolumn{10}{|c|}{ 1. Темпи приросту (зменшення) балансової вартості активів, \% до 2010 р. } \\
\hline харчові підприємства & - & 23,1 & 36,0 & 46,0 & 62,7 & 96,7 & 145,2 & 178,8 & 194,1 \\
\hline металургійні підприємства & - & 11,9 & 20,0 & 22,5 & 47,0 & 85,9 & 109,4 & 141,3 & 178,5 \\
\hline машинобудівні підприємства & - & 11,6 & 17,4 & 20,8 & 24,8 & 31,3 & 40,8 & 55,5 & 67,5 \\
\hline \multicolumn{10}{|c|}{ 2. Темпи приросту (зменшення) реалізованої продукції, \% до 2010 р. } \\
\hline харчові підприємства & - & 15,2 & 31,8 & 35,6 & 56,6 & 106,2 & 139,5 & 184,1 & 205,5 \\
\hline металургійні підприємства & - & 20,9 & 11,6 & 3,8 & 18,3 & 38,8 & 58,6 & 105,0 & 145,6 \\
\hline машинобудівні підприємства & - & 36,7 & 39,2 & 60,6 & 38,1 & 571,6 & 665,4 & 880,5 & 1115,9 \\
\hline \multicolumn{10}{|c|}{ 3. Рентабельність активів за чистим прибутком, \% } \\
\hline харчові підприємства & 1,23 & 1,03 & 2,91 & 2,47 & $-5,73$ & $-4,64$ & $-1,69$ & 1,76 & 2,91 \\
\hline металургійні підприємства & $-2,74$ & $-2,56$ & $-6,53$ & $-5,08$ & $-13,64$ & $-11,41$ & $-1,90$ & $-1,94$ & 0,17 \\
\hline машинобудівні підприємства & 2,85 & 6,46 & 5,35 & 1,55 & $-12,15$ & $-7,93$ & $-0,35$ & 2,67 & 3,04 \\
\hline
\end{tabular}

* Розраховано та формалізовано автором за даними [7]

Найменшими темпи зростання були на підприємствах машинобудування, при цьому зростаюча тенденція була стійкою. Якщо порівняти темпи зростання величини активів та обсягів продажу, то для харчових та машинобудівних підприємств динаміка $€$ позитивною, так як обсяги продажу зростали більш високими темпами ніж активи. Для металургійних підприємств при зростанні активів у 2018 р. порівняно 32010 р. на 178,5\% реалізована продукція збільшилася всього на 145,6\%.

Високі темпи зростання машинобудівної продукції у 2018 р. порівняно з 2010 р. пов’язані 3 одного боку 3 низькими показниками реалізації у 2010 р., які були наслідками кризи 2008 р., з іншого із зростанням з 2016 р. інтересу іноземних інвесторів до відкриття в Україні машинобудівних підприємств. При цьому варто акцентувати увагу на тому, що активізація іноземних інвесторів хоча, безумовно, і дуже позитивний крок для розвитку вітчизняної економіки, але український ринок приваблює інвесторів дешевизною робочої сили, тобто країна фактично продає людино-години, а не інтелектуальну продукцію, що навіть у такій наукомісткій галузі, як машинобудування, свідчить про ресурсно-орієнтовану модель розвитку.

Використовуючи методи кореляції для факторного аналізу вартості капіталу було отримано низку результатів (табл. 3), які дозволяють зробити такі змістовні узагальнення:

Показники кореляційної залежності вартості капіталу вибірки промислових підприємств України та ключових індикаторів вартісних результатів капіталотворення*

\begin{tabular}{|c|c|c|c|c|c|}
\hline \multirow[b]{2}{*}{$\begin{array}{c}\text { Підприємства вибір- } \\
\text { ки за видами проми- } \\
\text { слової діяльності }\end{array}$} & \multicolumn{5}{|c|}{ Шкала інтерпретації кореляційного зв’язку } \\
\hline & $\begin{array}{c}\mathbf{0 , 9}<\mathbf{r}=\mathbf{1 , 0 0} \\
\text { дуже сильна } \\
\text { кореляц̧ія } \\
\end{array}$ & $\begin{array}{c}\mathbf{0 , 7 0}<\mathbf{r}=\mathbf{0 , 9 0} \\
\text { сильна } \\
\text { корелячуія } \\
\end{array}$ & $\begin{array}{c}\mathbf{0 , 5 0}<\mathbf{r}=\mathbf{0 , 7 0} \\
\text { середня } \\
\text { корелячиія }\end{array}$ & $\begin{array}{c}\mathbf{0 , 2 0}<\mathbf{r}=\mathbf{0 , 5 0} \\
\text { слабка } \\
\text { кореляція } \\
\end{array}$ & $\begin{array}{c}\mathbf{0 , 0 0}<\mathbf{r}=\mathbf{0 , 2} \\
\text { дуже слабка } \\
\text { корелячія } \\
\end{array}$ \\
\hline $\begin{array}{l}\text { Підприємства вибір- } \\
\text { ки в цілому }\end{array}$ & $F V O C(0,98)$ & $\begin{array}{c}\text { ReOI }(-0,73) \\
\text { Sale }(0,86) \\
\text { Inv }(0,70)\end{array}$ & $F C F E(0,61)$ & $\begin{array}{c}\text { WACC }(0.21) \\
\text { Ass }(0,39)\end{array}$ & $\begin{array}{c}\text { Str.cap }(0.11) \\
\text { Borr.cap. }(0.12)\end{array}$ \\
\hline $\begin{array}{l}\text { Харчові підприємс- } \\
\text { тва }\end{array}$ & $\begin{array}{c}\text { FVOC }(0,94) \\
\text { Sale }(0,91)\end{array}$ & $\operatorname{Inv}(0,71)$ & $\begin{array}{c}\operatorname{Ass}(0,59) \\
F C F E(0,51)\end{array}$ & $\begin{array}{l}\operatorname{ReOI}(0,47) \\
W A C C(0.31)\end{array}$ & $\begin{array}{c}\text { Str.cap }(0,19) \\
\text { Borr.cap. }(0.18)\end{array}$ \\
\hline $\begin{array}{l}\text { Металургійні підп- } \\
\text { риємства }\end{array}$ & $F V O C(0,96)$ & $\begin{array}{l}\text { Sale }(0,83) \\
\text { Inv }(0,80)\end{array}$ & $\operatorname{Ass}(0,52)$ & $\operatorname{ReOI}(-0,41)$ & $\begin{array}{c}\text { Str.cap }(0.17) \\
\text { WACC }(0.17) \\
\text { Borr.cap. }(0.14) \\
\text { FCFE }(0,19)\end{array}$ \\
\hline $\begin{array}{l}\text { Машинобудівні під- } \\
\text { приємства }\end{array}$ & & $\begin{array}{c}\text { FVOC }(0,88) \\
\text { Sale }(0,87) \\
\text { Inv }(0,71)\end{array}$ & & $\begin{array}{c}\text { WACC }(0.29) \\
\text { Ass }(0,46) \\
\text { Borr.cap. }(0.27) \\
\text { FCFE }(0,49)\end{array}$ & $\begin{array}{l}\text { Str.cap }(0.17) \\
\operatorname{ReOI}(0,20)\end{array}$ \\
\hline
\end{tabular}

Примітка: Str.cap - ринкова капіталізація; FVOC - фундаментальна вартість операційного капіталу; Sale - виручка від продажу продукції; WACC - індекс якості капіталу; ReOI - остаточний операційний прибуток; Ass - величина активів за балансовою вартістю; Borr.cap. - величина кредитних ресурсів; $F C F E$ - чистий потік грошових коштів для власників.

*Розраховано та формалізовано авторами 
1) величина вартості капіталу досліджуваних промислових підприємств демонструє досить низький рівень залежності від показників, що характеризують структуру капіталу та витрати на капітал;

2) досить сильною є залежність вартості капіталу від таких факторів як обсяг капіталовкладень ( 0,7-0,8), виручка від продажу продукції (0,83-0,91), фундаментальна вартість операційного капіталу (0,88-0,98). Фактично, підтверджується одна із ключових тез теорії результативності капіталотворення, відповідно до якої рівень конкурентоспроможності підприємства $є$ базовим фактором формування вартості капіталу, як з точки зору ресурсного аспекту, так i в аспекті формування доданої вартості капіталу;

2) досить цікавим є отриманий результат щодо наявності зв'язків між величиною вартості капіталу та потоками вільних грошових коштів для власників, що свідчить про залежність результатів капіталотворення від достатності капіталу забезпечувати потребу у фінансуванні поточних та інвестиційних потреб бізнесу.

Визначаючи високий рівень залежності вартості капіталу промислових підприємств від величини виручки від продажу продукції та інвестицій виникає питання щодо доцільності здійснення більш грунтовного аналізу, який полягає у тому наскільки впливовими $є$ фактори якості інвестиційних вкладень, якості продукції та іiі конкурентоспроможності, ін.
Залежність фінансових результатів капіталотворення стає все більш очевидною від нефінансових фундаментальних факторів розвитку бізнесу, що актуалізує потребу у розвитку адекватних методів та інструментів вартісного аналізу.

Висновки та перспективи подальших досліджень. Отримані результати практичної апробації методичного підходу до оцінювання управлінської результативності капіталотврення промислових підприємств свідчить про те, що сучасна проблематика забезпечення зростання вартості зміщується в площину формування результатної складової. Тобто фактично підтверджується розхожа теза про те, що «необхідно більше заробляти, а не менше витрачати». При цьому у ході визначення управлінської результативності досить важливим моментом є ідентифікація та формалізація найбільш значущих факторів, які впливають на вартісні результати капіталотворення. Очевидним стає той факт, що такі фактори мають нефінансову природу, що актуалізує потребу у розвитку теорії управлінської результативності капіталотворення у напрямку пошуку адекватних методів та інструментів, які б дозволяли не тільки оцінювати нефінансові результати капіталотворення та їх вплив на формування вартості бізнесу, а i зв'язки між не економічними факторами впливу та їх пріоритетність 3 точки зору забезпечення вартісної цільової моделі діяльності підприємств.

\section{Література}

1. Арнольд Г. Руководство по корпоративным финансам: пособие по финансовым рынкам, решениям и методам / Арнольд Г.; пер. Епанов М. А., Максимова О. Б. Днепропетровск: Баланс Бизнес Букс, 2007.752 с.

2. Баффетт У. Эссе об инвестициях, корпоративных финансах и управлении компаниями. М.: Альпина Бизнес Букс, 2007. 268 с.

3. Брейли Р. Принципы корпоративных финансов. М.: Олимп-Бизнес, 2012. 978 с.

4. Бригхем Ю. Финансовый менеджмент. Полный курс. / Бригхем Ю.; пер. с англ. под ред. Дорофеева Е. А. СПб.: Экономическая школа, 1997. Т. 1. 497 с.; Т.2. 669 с.

5. Разумный инвестор: полное руководство по стоимостному инвестированию / Грэм Б.; пер. Башкиров В. М.: Альпина Паблишер, 2018. 568 с.

6. Дамодаран А. Инвестиционная оценка. Инструменты и техника оценки любых активов / Дамодаран А.; пер. Липинский Д., Розмаинский И., Скоробогатов А. М.: Альпина Паблишер, 2010. 1344 с.

7. Державна служба статистики України. Офіційний сайт. URL: www.ukrstat.gov.ua (дата звернення: 01.04.2021)

8. Коупленд Т. Expections-Based Management. Как достичь превосходства в управлении стоимостью компании / Коупленд Т.; пер. Кондукова Э.В. М.: Эксмо, 2009. 384 с.

9. Мельник О.В. Капіталізація підприємств: теорія та практика: монографія. Кам'янець-Подільський: Видавець Панькова А. С., 2020. 428 с.

10. Мендрул О.Г. Управління вартістю підприємства. навч. посіб. К.: КНЕУ, 2011. 538 с.

11. Олексюк О.І. Економіка результативності підприємства: монографія. К.: КНЕУ, 2008. 262 с.

12. Рябикіна К.Г. Ефективність управління капіталом підприємств. Монографія. Кривий ріг: Видавництво «Діонат» ФОП Чернявський Д.О., 2019. 200 с.

13. Фролова Л.В. Управління вартістю підприємства: монографія. Кривий Ріг: Видавництво «Діонат» ФОП Чернявський Д.О., 2015. 290 с. 


\author{
Vovchak 0. \\ Doctor of Economics, Professor \\ Department of Banking and Financial Technologies \\ University of Banking \\ Sichovykh Striltsiv str., 11, Lviv, Ukraine, 79007 \\ E-mail: vovchak.olga@meta.ua \\ ORCID ID: 0000-0002-8858-5386 \\ Melnyk 0. \\ Doctor of Economics, Associate Professor \\ Department of Economic Theory \\ Kyiv National Economic University n.a. Vadym Hetman \\ Prospect Peremogy, 54/1, Kyiv, Ukraine, 03057 \\ E-mail: kina44@gmail.com \\ ORCID ID: 0000-0002-2836-8945
}

\title{
COST ASPECTS OF MANAGEMENT EVALUATION OF CAPITAL FORMATION EFFICIENCY AT THE ENTERPRISE
}

The article presents the results of the development of methodological principles for evaluating the managerial effectiveness of capital formation, taking into account the modern achievements of the theory of enterprise value. The modern problem of cost estimation of capital formation results which consists in ambiguity of meaningful interpretations of cost (market, investment, internal, fundamental) as a criterion of estimation of capital results has been defined. The results of scientific streamlining of methods for estimating the cost of capital of the enterprise have been presented. According to the managerial approach to estimating the cost of capital, the priority of using the concept of economic profit was emphasized in comparison to the approach based on discounting cash flows, which is explained by the higher level of analytical potential of the economic profit model, managerial effectiveness of capital formation in the enterprise, including indicators: 1) the size and structure of the cost of capital; 2) structure and dynamics of value added of capital; 3) the structure of the spread of capital formation results; 4) cost growth. The practical approbation of the presented approach to the assessment of managerial efficiency of capital formation has been made according to the data of food, metallurgical and machine-building enterprises of Ukraine. Based on the use of the correlation dependence method, a factor analysis of the value of the studied domestic industrial enterprises has been made and the most influential fundamental factors of influence have been determined. The scientific novelty of the obtained results lies in the development of analytical tools for valuing the managerial effectiveness of capital formation in enterprises. The practical significance of the obtained results is to determine the most influential factors in terms of ensuring the growth of capital results of domestic industrial enterprises.

Key words: efficiency, capital formation, value, economic profit, value added of capital.

\section{References}

1. Arnold, G. (2007). Rukovodstvo po korporativnyim finansam: posobie po finansovyim ryinkam, resheniyam $i$ metodam. (M. A. Epanov \& O. B. Maksimova, Trans.). Balans Biznes Buks.

2. Baffett, U. (2007). Esse ob investitsiyah, korporativnyih finansah i upravlenii kompaniyami. Alpina Biznes Buks.

3. Breyli, R. (2012). Printsipyi korporativnyih finansov. Olimp-Biznes.

4. Brighem, Yu. (1997). Finansovyiy menedzhment. (E. A. Dorofeeva, Trans.) (Vol. 1). Ekonomicheskaya shkola.

5. Grem, B. (2018). Razumnyiy investor: polnoe rukovodstvo po stoimostnomu investirovaniyu. (V. M. Bashkirov, Trans.). Alpina Pablisher.

6. Damodaran, A. (2010). Investitsionnaya otsenka. Instrumentyi i tehnika otsenki lyubyih aktivov. (D. Lipinskiy, I. Rozmainskiy \& A. M. Skorobogatov, Trans.). Alpina Pablisher.

7. Derzhavna sluzhba statystyky Ukrainy. www.ukrstat.gov.ua

8. Kouplend, T. (2009). Expections-Based Management. Kak dostich prevoshodstva v upravlenii stoimostyu kompanii. (E. V. Kondukova, Trans.). Eksmo.

9. Melnyk, O. V. (2020). Kapitalizatsiia pidpryiemstv: teoriia ta praktyka. Vydavets Pankova A. S.

10. Mendrul, O. H. (2011). Upravlinnia vartistiu pidpryiemstva. KNEU.

11. Oleksiuk, O. I. (2008). Ekonomika rezultatyvnosti pidpryiemstva. KNEU. 
12. Riabykina, K. H. (2019). Efektyvnist upravlinnia kapitalom pidpryiemstv. Vydavnytstvo «Dionat» FOP Cherniavskyi D.O..

13. Frolova, L. V. (2015). Upravlinnia vartistiu pidpryiemstva. Vydavnytstvo «Dionat» FOP Cherniavskyi D.O.

Received 10 April 2021

Approved 24 April 2021

Available in Internet 21.07.2021

Цитування згідно ДСТУ 8302:2015

Вовчак О.Д., Мельник О.В. Вартісні аспекти управлінського оцінювання результативності капіталотворення на підприємстві // Економіка харчової промисловості. 2021. Т. 13, вип. 2. С. 22-28. doi: 10.15673/fie.v13i2.2036

Cite as APA style citation

Vovchak, O., \& Melnyk, O. (2021). Cost aspects of management evaluation of capital formation efficiency at the enterprise. Food Industry Economics, 13(2), 22-28. doi: 10.15673/fie.v13i2.2036 